\title{
Model Program Demam Berdarah Dengue, Peran Serta Masyarakat, serta Sanitasi Dasar di Kota Bandung
}

\author{
Titik Respati, ${ }^{1}$ Ardini Raksanagara, ${ }^{2}$ Henni Djuhaeni ${ }^{2}$ \\ ${ }^{1}$ Fakultas Kedokteran Universitas Islam Bandung, Indonesia \\ ${ }^{2}$ Departemen Ilmu Kesehatan Masyarakat Fakultas Kedokteran Universitas Padjadjaran Bandung, Indonesia
}

\begin{abstract}
Abstrak
Munculnya kembali demam berdarah sebagai masalah kesehatan masyarakat yang utama menunjukkan sulitnya mempertahankan kelangsungan program pencegahan dan pemberantasan penyakit ini. Pengetahuan yang memadai mengenai demam berdarah dengue (DBD) dan metode untuk mencegahnya harus dapat dimengerti oleh masyarakat sebelum mereka mau berpartisipasi aktif. Penelitian ini bertujuan menggambarkan faktor-faktor yang memengaruhi DBD berdasar atas peran serta masyarakat, sanitasi dasar, dan program pencegahan dan pemberantasan demam berdarah dengue Penelitian ini adalah survei pada 2.035 rumah tangga di 12 kecamatan dan 16 kelurahan di Kota Bandung pada bulan Mei - Juni 2015 yang dilakukan dengan metode stratified random sampling. Kuesioner digunakan untuk mengetahui karakteristik, pengetahuan mengenai DBD, pengalaman, persepsi risiko dan sikap dalam kejadian DBD, program DBD yang tersedia, serta fasilitas sanitasi dasar. Analisis data menggunakan partial least square (PLS). Hasil menunjukkan bahwa DBD dipengaruhi oleh keberadaan tempat perindukan nyamuk, fasilitas sanitasi dasar terutama sistem pembuangan air limbah (SPAL), Program DBD serta peran serta masyarakat terutama mengenai pengetahuan. Upaya paling efektif untuk mengurangi tempat perindukan ini adalah dengan menyediakan sarana sanitasi dasar yang dapat diakses oleh seluruh masyarakat serta upaya pemberantasan sarang nyamuk PSN yang sebaiknya dilakukan secara serentak.
\end{abstract}

Kata kunci: DBD, partisipasi masyarakat, sanitasi dasar

\section{Dengue Hemorrhagic Fever Program Model, Community Participation, and Basic Sanitation in Bandung City}

\begin{abstract}
The reemergence of dengue fever as a major public health problem presents difficulties in the sustainability of prevention and eradication programs for this disease. Community must have adequate knowledge on dengue hemorrhagic fever (DHF) and methods to prevent it before they have the willingness to participate actively. This study aimed to describe factors that influence DHF program ased on community participation, basic sanitation, and prevention and eradication. This was a survey on 2,035 households in 12 sub-districts and 16 villages in Bandung City in May-June 2015. Sampling was perfomed using stratified random sampling method. The questionnaire was used to determine the characteristics, knowledge on DHF, experience, risk perception, and attitudes towards the incidence of DHF; available DHF programs; and basic sanitation facilities. Data analysis was performed using Partial Least Square (PLS). The results showed that DHF was affected by the presence of mosquito breeding sites, basic sanitation facilities, especially sewage disposal systems (SPAL), DHF programs, and community participation especially knowledge. The most effective effort to reduce the breeding place is by providing basic sanitation facilities accessible to the entire community along with simultaneous efforts to eradicate mosquito breeding places.
\end{abstract}

Key words: Basic sanitation, community participation, DHF

Korespondensi: Dr. Titik Respati drg., MScPH, Fakultas Kedokteran Universitas Islam Bandung, Jalan Tamansari No. 22 Bandung, Email: titik.respati@gmail.com; titik.respati@unisba.ac.id 


\section{Pendahuluan}

Dalam 50 tahun terakhir kejadian demam berdarah dengue atau DBD meningkat 30 kali lipat. Penduduk dunia yang rentan berjumlah $50 \%$ dari total penduduk, yaitu 3 milyar orang dengan insidensi sebanyak 500-100 juta per tahun. ${ }^{1}$ Indonesia telah menjadi daerah endemis DBD sejak tahun 1968 dengan insidensi yang semakin meningkat dan telah menyebar di 33 provinsi dan 436 kabupaten/kota. DBD masih menjadi masalah kesehatan masyarakat yang utama karena penyebaran, tingkat keparahan, serta kerugian material yang dihasilkannya akan semakin meningkat apabila tidak dilakukan pencegahan dan pemberantasan penyakit ini secara dini. ${ }^{2}$ Sejak bulan Desember 2015 sampai akhir Januari 2016 Data Direktorat Pengendalian Penyakit Tular Vektor dan Zoonosis Kementerian Kesehatan menyatakan kejadian luar biasa (KLB) penyakit DBD dilaporkan ada di 9 kabupaten dan 2 kota dari 7 provinsi di Indonesia dengan jumlah kematian 25 orang. $^{3}$

Jawa Barat adalah salah satu provinsi yang memiliki angka kasus DBD yang paling tinggi di Indonesia. Pada tahun 2011 dan 2012 terdapat secara berturut-turut 19.663 dan 19.739 kasus DBD. Kota Bandung menjadi kota dengan angka kasus DBD paling tinggi di Jawa Barat. Terdapat sebanyak 3.822; 5.057; 5.127; dan 3.132 kasus di tahun 2011, 2012, 2013, dan tahun 2014 secara berurutan. ${ }^{3,4}$

Sampai saat ini belum ada obat atau vaksin yang efektif telah membatasi pilihan untuk melakukan pencegahan dan juga pengobatan untuk penyakit ini. ${ }^{5,6}$ Program yang selama ini dilakukan, yaitu memperbaiki manajemen kasus untuk mencegah kematian dan vektor kontrol untuk membatasi transmisi virus. Program ini memerlukan partisipasi masyarakat dalam pemeliharaan lingkungan rumah dan sekitar pemukiman mereka. ${ }^{7,8}$

Di Indonesia secara umum, upaya untuk pemberantasan sarang nyamuk demam berdarah dengue (PSN-DBD) merupakan aktivitas utama upaya pencegahan DBD yang melibatkan peran serta masyarakat. Program ini sudah dijalankan sejak tahun 1992 dengan gerakan 3M, yaitu Menguras-Menutup-Mengubur. Gerakan 3M ini pada tahun 2000 dikembangkan menjadi 3M Plus dengan tambahan penggunaan larvasida, memelihara ikan, dan mencegah gigitan nyamuk. ${ }^{5}$ Keberlangsungan program menjadi masalah utama dalam vektor kontrol terutama karena situasi yang sangat beragam. Rekomendasi dari beberapa penelitian menyatakan bahwa strategi vektor kontrol harus diintegrasikan dengan peran serta masyarakat yang kuat dan kerja sama lintas sektor. ${ }^{9}$ Dukungan politis sejak awal merupakan salah satu faktor yang menentukan keberhasilan suatu upaya pemberdayaan pada masyarakat. ${ }^{10}$

Pengetahuan yang memadai mengenai DBD dan metode untuk mencegahnya harus dapat dimengerti oleh masyarakat sebelum mereka mau berpartisipasi aktif. ${ }^{11,12}$ Persepsi tentang penyakit sangat memengaruhi keterlibatan masyarakat. ${ }^{13,14}$ Suatu penelitian lain di Indonesia telah mendapatkan bahwa persepsi seseorang terhadap nyamuk yang hanya dianggap sebagai pengganggu dan bukan penyebab dari penyakit memengaruhi keterlibatan dalam aktivitas pemberantasan sarang nyamuk (PSN). ${ }^{15,16}$ Penelitian ini bertujuan menggambarkan faktorfaktor yang mempengaruhi DBD berdasar atas peran serta masyarakat, sanitasi dasar, dan program pencegahan dan juga pemberantasan demam berdarah dengue

\section{Metode}

Penelitian ini adalah bagian dari penelitian berjudul Model Dinamika Sistem Ecohealth untuk Mengurangi Tempat Perindukan Nyamuk Sebagai Upaya Memotong Transmisi Demam Berdarah Dengue. Penelitian ini telah mendapat izin etik penelitian No. 464/UN6.c2.1.2/KEPK/ PN/2014 dari Fakultas Kedokteran Universitas Padjadjaran serta Badan Kesatuan Bangsa dan Perlindungan Masyarakat Daerah (BKBPMD) No. 070/3799/BKBPM.

Penelitian ini adalah penelitian observasional analitik eksplorasi survei. Pengambilan sampel dilakukan dengan metode stratified random sampling. Instrumen pengambil data yang dipergunakan adalah kuesioner untuk rumah tangga serta daftar tilik untuk survei entomologi. Sebelum instrumen pengambilan data dipergunakan dilakukan uji coba kuesioner pada 200 responden $(10 \%$ dari target sampel penelitian) yang mempunyai karakteristik yang sama dengan populasi penelitian di salah satu kelurahan di Kota Bandung.

Survei rumah tangga dan survei entomologi dilakukan oleh enumerator yang telah dilatih. Enumerator yang digunakan adalah mahasiswa kesehatan lingkungan Poltekkes Bandung yang bekerja dalam tim beranggotakan dua orang. Sebelum pengambilan data dilaksanakan para enumerator telah dilatih dengan materi pelatihan berupa survei jentik yang diberikan 
Titik Respati dkk.: Model Program Demam Berdarah Dengue, Peran Serta Masyarakat, serta Sanitasi Dasar di Kota Bandung

Tabel 1 Evaluasi Model Program DBD untuk Tempat Perindukan

\begin{tabular}{lccccc}
\hline \multicolumn{1}{c}{ Faktor } & AVE & $\begin{array}{c}\text { Composite } \\
\text { Reliability }\end{array}$ & R-Square & $\begin{array}{c}\text { Cronbachs } \\
\text { Alpha }\end{array}$ & Communality \\
\hline Peran serta masyarakat & 0,351 & 0,548 & & 0,226 & 0,351 \\
Sanitasi dasar & 0,344 & 0,234 & 0,027 & $-0,011$ & 0,344 \\
Program DBD & 0,281 & 0,657 & 0,145 & 0,371 & 0,281 \\
Tempat perindukan & 0,820 & 0,901 & 0,026 & 0,783 & 0,820 \\
\hline
\end{tabular}

oleh staf Bagian Parasitologi Fakultas Kedokteran Universitas Padjadjaran. Kuesioner survei rumah tangga yang diberikan menggali informasi khusus, yaitu informasi umum responden, pengetahuan mengenai demam berdarah, pengalaman dengan demam berdarah, pengetahuan mengenai gejala demam berdarah, persepsi mengenai demam berdarah, dan praktik upaya pencegahan. Pengisian kuesioner dilakukan oleh surveior karena beberapa pernyataan membutuhkan jawaban spontan langsung dari responden.

Survei entomologi dilakukan menggunakan instrumen pengumpulan data hasil modifikasi dari World Health Organization on behalf of the Special Programme for Research and Training in Tropical Diseases. ${ }^{14}$ Setiap kontainer di tiaptiap rumah dikelompokkan berdasar atas tempat, jenis bahan, diameter, kapasitas, status tutup (tertutup/semi tertutup/terbuka), warna (terang/gelap), paparan terhadap sinar matahari, serta upaya pencegahan misalnya penggunaan abate atau aktivitas memelihara ikan. Hanya kontainer yang berisi air yang diperiksa. Metode survei jentik yang dipergunakan adalah metode visual.

Analisis yang dipilih ialah structural equation model (SEM) yang menganalisis variabel indikator, variabel laten, serta kekeliruan pengukurannya. Pengukuran yang dilakukan dengan SEM antara lain analisis hubungan antara variabel indikator dan variabel laten (measurement equation), hubungan antara variabel laten satu dan variabel laten lainnya (structural equation), serta secara bersama sama melibatkan kekeliruan pengukuran. Penelitian ini menggunakan SEM berbasiskan variance, selanjutnya akan disebut dengan partial least squares path modeling (PLS-PM). Pertimbangan penggunaan analisis ini adalah sebagai berikut: data tidak terdistribusi normal ukuran sampel yang besar $(>1.000)$.

\section{Hasil}

Dua buah gambar berikut menunjukkan hasil pengujian menggunakan partial least square (PLS) pada hasil survei rumah tangga dan entomologi. Gambar 1 adalah hasil PLS berdasar atas survei rumah tangga untuk melihat hubungan rumah dengan lingkungan sekitarnya yang diwakili oleh sarana sanitasi dasar berupa SPAL, sumber air dan tempat sampah, peran serta masyarakat, serta program DBD dengan tempat perindukan yang berada di dalam dan di luar rumah. Gambar 2 adalah hasil PLS berdasar atas observasi langsung enumerator yang sekaligus melakukan suvei jentik pada rumah tangga yang sama dengan survei rumah tangga. Observasi dilakukan pada beberapa variabel yang juga ditanyakan terhadap responden untuk

Tabel 2 Signifikansi Pengaruh Antarfaktor untuk Tempat Perindukan

\begin{tabular}{lccc}
\hline \multicolumn{1}{c}{ Pengaruh Antarfaktor } & Besaran Pengaruh & Nilai t & Nilai p \\
\hline Peran serta masyarakat - Program DBD & 0,361 & 16,522 & $0,000^{*}$ \\
Peran serta masyarakat - Sanitasi dasar & $-0,165$ & 3,137 & $0,002^{*}$ \\
Peran serta masyarakat - Tempat perindukan & 0,126 & 2,851 & $0,004^{*}$ \\
Program DBD - Tempat perindukan & $-0,156$ & 5,684 & $0,000^{*}$ \\
Sanitasi dasar - Program DBD & $-0,076$ & 3,197 & $0,001^{*}$ \\
Sanitasi dasar - Tempat perindukan & $-0,011$ & 0,317 & 0,751 \\
\hline
\end{tabular}

Keterangan: * signifikan 


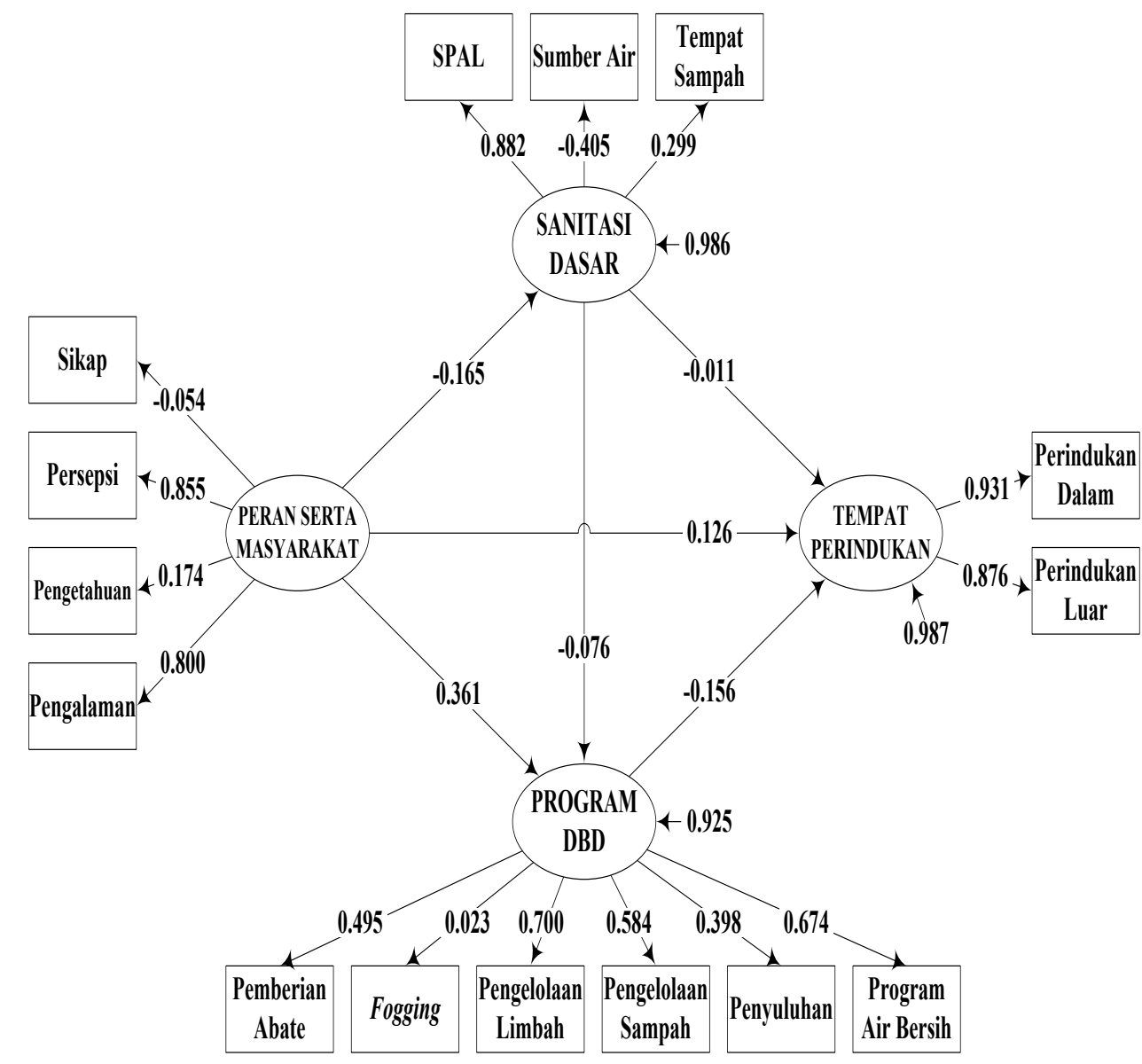

\section{Gambar 1 Model Peran Serta Masyarakat, Sanitasi Dasar, dan Program DBD terhadap Tempat Perindukan Nyamuk DBD}

melihat kesesuaian data. Variabel yang diamati adalah tempat perindukan di dalam dan di luar rumah, sarana sanitasi dasar, dan keberadaan jentik nyamuk. Bagan hasil PLS dapat dilihat pada Gambar 1 dan Gambar 2.

Hasil pengujian model dievaluasi dengan average variance extracted (AVE) composite reliability, R-square, dan Cronbach Alpha dengan hasil pada tabel. Composite reliability dipergunakan untuk melihat konsistensi internal, nilai minimal 0,7 untuk dapat dikatakan adekuat. Untuk mengevaluasi validitas diskriminan dipergunakan average variance extracted (AVE) dengan nilai minimal 0,5.

Tabel 1 menunjukkan bahwa faktor peran serta masyarakat, sanitasi dasar, dan program

Tabel 3 Evaluasi Model Tempat Perindukan dan Jentik

\begin{tabular}{lccccc}
\hline & AVE & Composite Reliability & $\boldsymbol{R}$ Square & $\begin{array}{c}\text { Cronbachs } \\
\text { Alpha }\end{array}$ & Communality \\
\hline Sanitasi dasar & 0,586 & 0,738 & & 0,298 & 0,586 \\
SAB & 1,000 & 1,000 & 0,000 & 1,000 & 1,000 \\
Rumah sehat & 0,530 & 0,656 & 0,115 & 0,175 & 0,530 \\
Kontainer & 0,207 & 0,426 & 0,145 & 0,214 & 0,207 \\
Tempat perindukan & 0,763 & 0,866 & 0,048 & 0,690 & 0,763 \\
Jentik & 0,555 & 0,814 & 0,005 & 0,755 & 0,555 \\
\hline
\end{tabular}


Titik Respati dkk.: Model Program Demam Berdarah Dengue, Peran Serta Masyarakat, serta Sanitasi Dasar di Kota Bandung

Tabel 4 Signifikansi Pengaruh Antarfaktor untuk Tempat Perindukan

\begin{tabular}{lccc}
\hline \multicolumn{1}{c}{ Pengaruh Antarfaktor } & Besaran Pengaruh & t-value & nilai p \\
\hline Sanitasi dasar - Sumber air & 0,008 & 0,487 & 0,626 \\
Sanitasi dasar - Kondisi rumah & 0,338 & 15,417 & $0,000^{*}$ \\
Sanitasi dasar -Tempat perindukan & 0,141 & 6,971 & $0,000^{*}$ \\
Sumber air - Kondisi rumah & 0,017 & 1,183 & 0,237 \\
Sumber air - Kontainer & $-0,381$ & 23,513 & $0,000^{*}$ \\
Sumber air - Tempat perindukan & 0,087 & 6,214 & $0,000^{*}$ \\
Kondisi rumah - Tempat perindukan & 0,092 & 5,717 & $0,000^{*}$ \\
Kontainer - Tempat perindukan & 0,074 & 4,399 & $0,000^{*}$ \\
Tempat perindukan - Jentik & $-0,073$ & 6,504 & $0,000^{*}$ \\
\hline
\end{tabular}

Keterangan: * signifikan

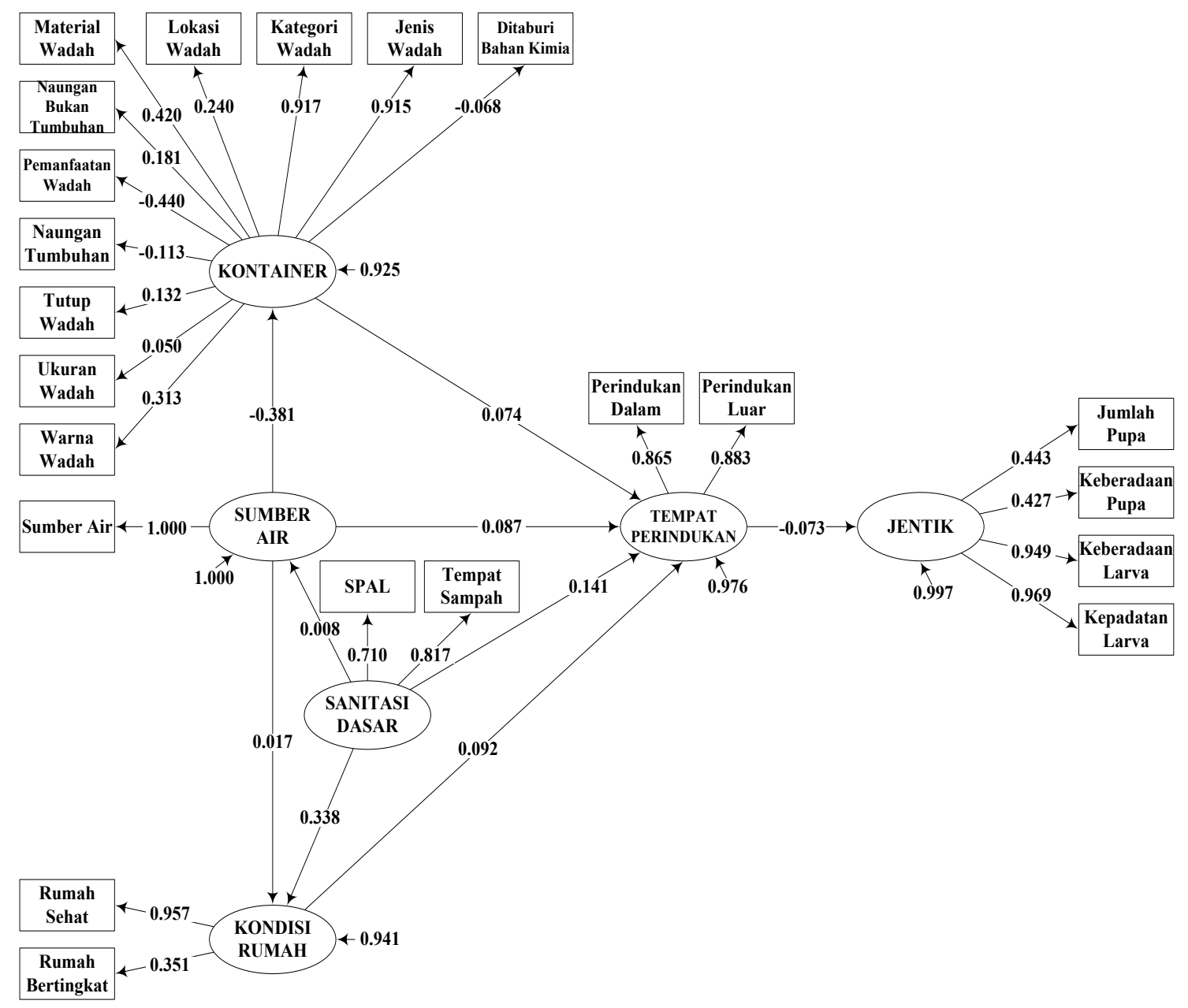

Gambar 2 Model Pengaruh Sanitasi Dasar, Kondisi Rumah, Sumber Air, dan Kontainer terhadap Tempat Perindukan dan Jentik 
DBD mempunyai nilai AVE di bawah 0,50, sedangkan faktor tempat perindukan memiliki nilai AVE di atas 0,50. Perolehan R-square untuk sanitasi dasar, program DBD, dan tempat perindukan tergolong rendah, yaitu 0,027, 0,145 , dan 0,026 secara berurutan. Peran serta masyarakat memengaruhi sanitasi dasar sebesar 2,7\%; peran serta masyarakat dan sanitasi dasar memengaruhi program DBD sebesar 14,5\%; serta peran serta masyarakat, sanitasi dasar, dan program DBD memengaruhi tempat perindukan sebesar 2,6\%. Berdasar atas nilai-nilai tersebut, peneliti menyimpulkan bahwa model hipotesis dapat diterima karena beberapa ukuran evaluasi model berada di atas ambang batas.

Tabel 2 menunjukkan bahwa pengaruh peran masyarakat terhadap program DBD signifikan dengan besaran 0,361. Berdasar atas kriteria effect-size, pengaruh ini bersifat kuat karena lebih besar daripada 0,35 . Pengaruh peran serta masyarakat terhadap sanitasi dasar sebesar $-0,165$. Pengaruh ini bersifat substansial karena masih dalam rentang 0,16-0,35. Pengaruh peran serta masyarakat terhadap tempat perindukan tergolong moderat karena masih dalam rentang $0,02-0,15$, yaitu sebesar 0,126 .

Gambar 2 merupakan model PLS untuk Model Pengaruh Sanitasi Dasar, Kondisi Rumah, Sumber Air, dan Kontainer terhadap Tempat Perindukan dan Keberadaan Jentik. Keberadaan jentik menjadi indikator pencapaian program yang diukur dengan melihat keberadaan pupa dan larva serta jumlah pupa dan estimasi kepadatan larva.

Kontainer sebagai tempat perindukan nyamuk yang utama dilihat berdasar atas warna, ukuran, pemanfaatan, material, lokasi, dan jenis material. Selain itu, di amati keberadaan tutup, naungan tumbuhan dan pemanfaatan selama 7 hari terakhir. Hasil pengujian model kembali dievaluasi dengan menggunakan average arviance extracted (AVE), composite reliability, $R$-square, dan Cronbach Alpha dengan hasil dapat di lihat pada Tabel 3 berikut.

Faktor kontainer memiliki nilai AVE di bawah 0,50; sedangkan faktor sanitasi dasar, sumber air, kondisi rumah dan jentik, serta tempat perindukan memiliki nilai AVE di atas 0,50. Perolehan $R$-square untukrumah sehat, kontainer, dan tempat perindukan tergolong rendah, yaitu 0,115 ; 0,145; dan 0,046 masing-masing. Hal ini berarti bahwa SAB hanya memengaruhi rumah sehat sebesar 11,5\%; rumah sehat dan $\mathrm{SAB}$ memengaruhi kontainer sebesar $14,5 \%$; rumah sehat, SAB, dan kontainer memengaruhi tempat perindukan sebesar 4,8\%. Keseluruhan variabel di atas hanya memengaruhi jentik sebanyak $0,5 \%$.

Tabel 4 memperlihatkan bahwa pengaruh sumber air terhadap kontainer signifikan dengan besaran $-0,381$. Berdasar atas kriteria effect-size, pengaruh ini bersifat kuat karena lebih besar daripada 0,35. Pengaruh sanitasi dasar dengan kondisi rumah sebesar 0,338 bersifat substansial karena masih dalam rentang 0,16-0,35. Pengaruh sanitasi dasar terhadap tempat perindukan $(0,141)$; sumber air terhadap tempat tempat perindukan $(0,087)$; kondisi rumah terhadap tempat perindukan $(0,092)$; dan kontainer terhadap tempat perindukan $(0,074)$ serta tempat perindukan terhadap jentik $(-0,073)$ tergolong moderat karena masih dalam rentang $0,02-0,15$.

\section{Pembahasan}

Pada DBD aktivitas pencegahan yang paling penting dilakukan oleh masyarakat adalah PSNDBD yang berhubungan erat dengan tersedianya kontainer di rumah. Hasil survei menunjukkan beberapa daerah dengan mayoritas penduduk tergolong dalam ekonomi rendah ternyata mempunyai indeks entomologi yang lebih baik dibanding dengan wilayah dengan penduduk yang memiliki tingkat sosial ekonomi yang lebih baik. Hasil ini masih perlu dicermati karena pada penelitian ini hanya menjadikan informasi mengenai pendapatan sebagai proksi status ekonomi responden yang belum menggambarkan status ekonomi yang sebenarnya. Berdasar atas pengamatan, kader di daerah tersebut biasanya berperan lebih aktif dalam kegiatan PSN-DBD serta aktivitas yang berhubungan dengan kesehatan lainnya. Peranan kader dalam aktivitas PSN-DBD tampaknya sangat penting dalam keberhasilan program DBD. Kemampuan untuk mempertahankan ketertarikan kader untuk tetap berpartisipasi dalam kegiatan harus menjadi perhatian pemegang program. ${ }^{8,9}$

Pengetahuan yang memadai mengenai DBD dan metode untuk mencegahnya harus dapat dimengerti oleh masyarakat sebelum mereka mau berpartisipasi aktif. Monitoring serta feedback yang dilakukan secara berkala terutama kepada tingkat yang paling rendah seperti keluarga meningkatkan keberhasilan program pencegahan DBD. Persepsi tentang penyakit sangat memengaruhi keterlibatan masyarakat. ${ }^{7}$ Suatu penelitian lain di Indonesia mendapatkan bahwa persepsi seseorang terhadap nyamuk yang dianggap sebagai pengganggu dan bukan 
penyebab penyakit memengaruhi keterlibatan dalam aktivitas PSN-DBD. ${ }^{5,16}$

Program demam berdarah sampai saat ini masih menjadi program yang berasal dari pemerintah sehingga masyarakat menyerahkan tanggung jawab program ini sebagian besar atau seluruhnya kepada pemerintah dan tidak menyadari pentingnya peran mereka sebagai sebuah komunitas dalam program ini. Aktivitas masyarakat dalam pencegahan diharapkan berlangsung secara terus menerus, akan tetapi keadaan ini sulit dilaksanakan selama program tersebut masih dianggap sebagai program pemerintah. Banyak penelitian menyatakan bahwa keterlibatan masyarakat akan lebih baik dan bertahan lama apabila mereka dilibatkan dalam awal program untuk menentukan masalah dan mencari solusi sendiri. ${ }^{7,14}$

Pada penelitian ini, pengalaman dalam demam berdarah baik yang diderita sendiri, anggota keluarga, kerabat maupun tetangga tidak menunjukkan hubungan dengan pengetahuan baik mengenai gejala maupun cara pencegahan. Pengalaman juga tidak berhubungan dengan sikap dalam pencegahan. Status pendidikan dan tingkat pendapatan yang rendah mungkin menjadi penyebab masih banyaknya responden yang mempunyai tingkat pengetahuan kurang. ${ }^{8}$ Kemampuan untuk secara komprehensif menghubungkan pengalaman tersebut dengan pengetahuan yang diperoleh tidak didapatkan. Keadaan lain yang dapat menjadi penyebab rendahnya tingkat pengetahuan adalah karena program dengue adalah program yang telah berjalan sangat panjang dengan PSN-DBD sebagai aktivitas utama sehingga masyarakat menjalankan aktivitas tersebut secara automatis tanpa merasa perlu untuk mengetahui alasannya.

Beberapa penelitian sudah menunjukkan hubungan yang kuat antara aktivitas promosi kesehatan dan inovasi dalam program dengue dalam meningkatkan praktik pencegahan demam berdarah terutama aktivitas PSN-DBD. Sebagaimana program kesehatan lain yang memerlukan partisipasi masyarakat, kebaruan dalam pendekatan dari program tersebut harus mendapat perhatian baik dari pemerintah, petugas kesehatan, maupun masyarakat. ${ }^{5,7}$

Persepsi mengenai risiko DBD menunjukkan hubungan dengan pengalaman dan pengetahuan serta sikap mengenai demam berdarah. Masyarakat yang mengalami sakit secara personal biasanya akan mencari informasi atau mendapatkan informasi yang lebih banyak mengenai penyakit tersebut secara langsung maupun tidak langsung. Hasil ini tidak sesuai dengan penelitian di Cuba yang menyatakan tidak ada hubungan antara persepsi mengenai risiko suatu penyakit dan sikap mengenai demam berdarah. ${ }^{17}$

Simpulan penelitian ini adalah bahwa program pencegahan dan pengendalian demam berdarah, peran serta masyarakat, serta sanitasi dasar mempengaruhi tempat perindukan. Upaya paling efektif untuk mengurangi tempat perindukan ini adalah dengan menyediakan sarana sanitasi dasar yang dapat diakses oleh seluruh masyarakat serta upaya PSN yang sebaiknya dilakukan secara serentak.

\section{Ucapan Terima Kasih}

Terima kasih kami sampaikan pada seluruh responden penelitian, Dinas Kesehatan Kota Bandung, dan Poltekes Bandung.

\section{Daftar Pustaka}

1. WHO. Treatment, prevention and control global strategy for dengue prevention and control 2. Tersedia dari: http://Apps.who.int/Iris/tstre am/10665/75303/1/9789241504034_Eng. pdf

2. Badan Penelitian dan Pengembangan Kesehatan. Riset kesehatan dasar. Jakarta: Litbangkes; 2013.

3. Kemenkes RI. Profil Kesehatan Indonesia [Internet]. Budijanto D, Yudianto, Booga $\mathrm{H}$, Titi S, penyunting. Vol. 70. Jakarta: Kementrian Kesehatan Republik Indonesia; 2016. hlm. 1780-790.

4. Respati T, Raksanagara A, Djuhaeni H, Sofyan A. Spatial distribution of dengue hemorrhagic fever (DHF) in urban setting of bandung city distribusi spasial kasus demam berdarah dengue di daerah urban Kota Bandung. GMHC. 2017;5(22):212-8.

5. Respati T, Raksanagara A, Djuhaeni H, Sofyan A, Shandriasti A. Ecohealth system dynamic model as a planning tool for the reduction of breeding sites. IOP Conf Ser Mater Sci Eng. 2017;180012108:1-9.

6. Mulligan K. Dengue and development: a critical political ecology. Hamilton: McMaster University; 2013.

7. Faridah L, Respati T, Sudigdoadi S, Sukandar H. Gambaran partisipasi masyarakat terhadap pengendalian vektor melalui kajian tempat perkembangbiakan Aedes aegypti di kota Bandung. MKB. 2017;49(1):43-7. 
8. Respati T, Nurhayati E, Feriandi Y, Yulianto F, Sakinah K. Pemanfaatan kalender 4M sebagai alat bantu meningkatkan peran serta masyarakat dalam pemberantasan dan pencegahan demam berdarah. GMHC. 2016;4(2):121-8.

9. Arunachalam N, Tyagi BK, Samuel M, Krishnamoorthi R, Manavalan R, Tewari SC, dkk. Community-based control of aedes aegypti by adoption of eco-health methods in Chennai. Pathog Glob Health. 2012;106(8):488-96.

10. Pablos-Mendez A, Shademani R.. Knowledge translation in global health. J Contin Educ Health Prof. 2006;26(1):81-6.

11. Depkes RI. Data Kasus DBD per Bulan di Indonesia Tahun 2010, 2009, dan 2008. Jakarta: Depkes RI; 2010.

12. Ohba S-Y, Kashima S, Matsubara H, Higa Y, Piyaseeli UKD, Yamamoto H, dkk. Mosquito Breeding sites and people's knowledge of mosquitoes and mosquito borne diseases: a comparison of temporary housing and nondamaged village areas in Sri Lanka after the tsunami strike in 2004. Trop Med Health. 2010;38(2):81-6.
13. Khan K, McNabb SJ, Memish ZA, Eckhardt R, Hu W, Kossowsky D, dkk. Infectious disease surveillance and modelling across geographic frontiers and scientific specialties. Lancet Infect Dis. 2012;12(3):222-30

14. Tana S, Abeyewickreme W, Arunachalam N, Espino F, Kittayapong P, Wai K, dkk. Eco-biosocial research on dengue in asia: general principles and a case study from Indonesia. Vol. 1, Ecohealth Research In Practice. Innovative Applications of An Ecosystem Approach To Health. 2012. hlm. 255-71.

15. Pujiyanti A, Triratnawati A. Pengetahuan dan pengalaman ibu rumah tangga atas nyamuk demam berdarah dengue. Makara. 2011;15(1):6-14.

16. Respati T, Raksanegara A, Djuhaeni H, Sofyan A, Agustian D, Faridah L, dkk. Berbagai faktor yang memengaruhi kejadian demam berdarah dengue di kota Bandung. Aspirator. 2017;9(2):91-6.

17. Vanlerberghe V, Toledo Me, Rodríguez $M$, Gómez D, Baly A, Benítez Jr, dkk. Community involvement in dengue vector control: cluster randomised trial. BMJ. 2009;338:b1959. 